\title{
COMO A DISPONIBILIDADE DE CONCHAS DE GASTRÓPODES AFETA O DESENVOLVIMENTO DE POPULAÇÕES DE LOXOPAGURUSLOXOCHELIS?
}

\author{
Galli, G.M. ${ }^{1}$; Stanski,G. ${ }^{1}$ \& Castilho, A.L. ${ }^{1}$ \\ ${ }^{1}$ Universidade Estadual Paulista (UNESP), Campus Botucatu, Núcleo de Estudos em Biologia, Ecologia e Cultivo de \\ Crustáceos (Nebecc). \\ *Autor correspondente: gimielligalli@gmail.com
}

\begin{abstract}
Os ermitões têm grande interesse para ciência pela estratégia em usar uma concha vazia de gastrópode como proteção. A fim de verificar como uma espécie desse grupo responde a condições ambientais diferenciadas, principalmente quanto à disponibilidade e diversidade de conchas de gastrópodes, investigamos populações de Loxopagurus loxochelis habitando condições ambientais particulares. Os animais foram coletados mensalmente de julho de 2013 a junho de 2014 em Macaé, Ubatuba e Cananéia, em profundidades entre 5 a 20 m, utilizando barcos camaroeiros com redes "doublerig". Em laboratório, os ermitões foram retirados de suas conchas e ambos identificados e mensurados, o volume $(\mathrm{mL})$ e a largura da abertura $(\mathrm{mm})$ foram mensurados nas conchas, e nos ermitões o comprimento do escudo cefalotoráxico $(\mathrm{mm})$ foi mensurado, também foram realizadas 6 medidas aos quelípodos do primeiro par de pereópodos, ou seja: largura do própodo direito (LPD), largura do própodo esquerdo (LPE), altura do própodo esquerdo (APE), altura do própodo direito (APD), comprimento total do própodo esquerdo (CPE), e comprimento total do própodo direito (CPD). Encontramos diferença no tamanho dos animais entre as regiões (Anova, $\mathrm{p}<0.05$ ); no comprimento, largura e altura dos própodos tanto esquerdo como direito (Ancova, $\mathrm{p}<0.05$ ); e na riqueza de conchas de espécies de gastrópodes utilizadas. Ubatuba foi a região que apresentou maior número de espécies de conchas de gastrópodes utilizadas (15), e também os maiores animais. Além disso, foi a região onde ocorreu os valores de coeficientes de determinação $\left(R^{2}\right)$ mais elevados principalmente entre comprimento do escudo cefalotoráxico vs volume da concha, condição que evidencia conchas adequadas para o animal. O tamanho corporal e as variáveis analisadas do própodo não diferem nas populações de Macaé e Cananéia, além disso, nas regressões com todas as conchas ocupadas por região, Macaé e Cananéia apresentaram baixos valores de $\mathrm{R}^{2}$. Mediante esses resultados, sugerimos que tanto em Macaé como em Cananéia a disponibilidade de conchas adequadas interfere no crescimento dos ermitões, portanto, as diferenças encontradas são reflexos da divergência das condições ambientais das regiões investigadas, caracterizando um efeito regional no tamanho médio dos indivíduos de populações de Loxopagurus loxochelis.
\end{abstract}

Palavras-chave: partilha de habitat, recursos ambientais, Anomura. 